\title{
THE PROBLEMS AND CONDITIONS OF EFFECTIVE PUBLIC PARTICIPATION IN CREATING A SMART SUSTAINABLE CITY
}

\author{
Natal'ya I. Matova \\ Branch of the Institute of Natural and Technical Systems, Sochi, Russian Federation
}

\begin{abstract}
The technological arrangement of sustainable development ideas into modern life of cities is represented in the concept of a smart sustainable city. The evolution of smart settlements has convincingly proved that one of the key benefits of a smart city and, accordingly, a criterion for achieving smart sustainability, is the involvement and participation of citizens in public life. At the same time, it is important to understand that public participation is not only a criterion, but also a tool for achieving sustainable local development. Unfortunately, this fact is not adequately recognized by the domestic system of the public and municipal administration. As a result of the existing vision the Russian State strategy and the corresponding Programmes of introducing the concept of a smart sustainable city in municipal management practices appeared. This is happening the way that is traditional for our country: through the "top-down" introduction. Public participation, various institutional and informal forms of it face a number of problems in the current Russian conditions, which do not allow using the potential of social involvement in the formation of sustainable settlements to the fullest extent. The most important problems are the lack of public confidence in the institutions of power and the conviction that it is impossible to influence their actions, as well as the lack of knowledge and experience of self-organization of joint activities, insufficient awareness of their civil rights and forms of their realization, low level of self-awareness. Conclusion: the key condition for using modern organizational and economic tools to ensure the effective operation of communities, including the use of the "Smart city" project, is training, technology transfer, dissemination of knowledge and best practices, not only among inhabitants and activists, but also among officials and other decision-makers with public participation.

Key words: smart sustainable city, public participation, local government, community, national project, citizen

Citation. Matova N.I. The Problems and Conditions of Effective Public Participation in Creating a Smart Sustainable City. Vestnik Volgogradskogo gosudarstvennogo universiteta. Seriya 3, Ekonomika. Ekologiya [Science Journal of Volgograd State University. Global Economic System], 2019, vol. 21, no. 2, pp. 65-77. (in Russian). DOI: https://doi.org/10.15688/jvolsu3.2019.2.6
\end{abstract}

УДК 334.021 .1

Дата поступления статьи: 11.04.2019

ББК 65.209

Дата принятия статьи: 06.05.2019

\section{ПРОБЛЕМЫ И УСЛОВИЯ ЭФФЕКТИВНОГО ОБЩЕСТВЕННОГО УЧАСТИЯ В ФОРМИРОВАНИИ «УМНОГО» УСТОЙЧИВОГО ГОРОДА}

\author{
Наталья Ивановна Матова \\ Институт природно-технических систем (Филиал), г. Сочи, Российская Федерация
}

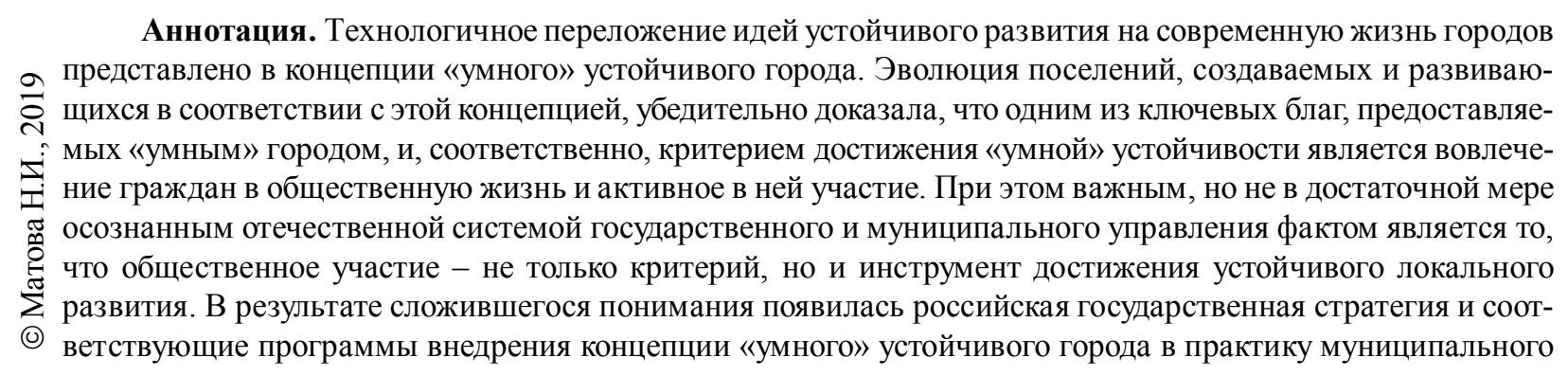


управления. Происходит это традиционным для нашей страны путем внедрения «сверху вниз». Общественное участие, различные институциональные и неформальные его формы сталкиваются в современных российских условиях с рядом проблем, не позволяющих использовать потенциал социальной вовлеченности в формирование устойчивых поселений в полной мере. Важнейшие проблемы - это дефицит доверия населения к институтам власти и убежденность в невозможности повлиять на их действия, а также отсутствие знаний и опыта самоорганизации совместной деятельности, недостаточная информированность о своих гражданских правах и формах их реализации, низкий уровень самосознания. Вывод: ключевым условием применения современных организационных и экономических инструментов и механизмов, обеспечивающих эффективную деятельность сообществ, в том числе с использованием возможностей проекта «Умный город», является обучение, передача технологий, распространение знаний и лучших практик, причем не только среди жителей и активистов, но и среди чиновников и других лиц, принимающих решение с участием общественности.

Ключевые слова: «умный» устойчивый город, общественное участие, местное самоуправление, сообщество, национальный проект, гражданин.

Цитирование. Матова Н. И. Проблемы и условия эффективного общественного участия в формировании «умного» устойчивого города // Вестник Волгоградского государственного университета. Серия 3, Экономика. Экология. - 2019. - Т. 21, № 2. - C. 65-77. - DOI: https://doi.org/10.15688/jvolsu3.2019.2.6

\section{Введение}

Развитие концепции устойчивого развития, происходившее в результате многочисленных теоретических исследований, разработки методологии и осуществления различных практик ее применения в реальных условиях городов, регионов, стран, привело к более глубокому и детальному пониманию условий и механизмов, обеспечивающих устойчивость жизнедеятельности территорий. В последние годы все больше внимания уделяется роли общества в данном процессе, причем общественное участие и социальная вовлеченность рассматриваются и как фактор, и как критерий, целевой показатель устойчивости поселений. В европейской практике «умных» устойчивых городов используется лозунг «Smart City - это Smart-сообщества людей» [Mapping ...].

Традиционно в нашей стране системы государственной власти и муниципального управления при осуществлении возложенных на них функций в социальной, социально-экономической и социально-экологической сферах рассматривают население лишь как управляемую систему и как пассивного получателя общественных благ. Такой подход к распределению ролей в регулируемых со стороны властей общественных процессах (таких как благоустройство общественных пространств, совершенствование жилищой инфраструктуры, создание и поддержание общественных мест отдыха, сохранение окружающей при- родной среды, помощь незащищенным и находящимся в трудных условиях группам людей и животных и т. п.) заключает в себе ряд недостатков. Во-первых, не используется творческий потенциал и трудовой ресурс населения как участника деятельности по осуществлению социальных проектов, ведь каждый человек как элемент общества - носитель профессиональных компетенций и личностных способностей. Общественные проекты - сфера, в которой может формироваться, совершенствоваться и находить свое применение человеческий капитал. Во-вторых, непосредственное участие населения в формировании решений по вопросам городской жизни и осуществлении общественно значимых проектов формирует ответственность жителей за жизнь в своем городе или поселке. Следует отметить, что во властных структурах приходит осознание ценности вовлечения населения, что нашло свое отражение, например, в основных принципах Приоритетного проекта Минстроя РФ «Формирование комфортной городской среды», первый из которых сформулирован как «общественное участие» посредством вовлечения жителей в работу и организация диалога местных сообществ [Приоритетный проект ..., 2018].

Тема повышения эффективности общественного участия в формировании «умных» устойчивых городов соответствует национальным целям и стратегическим задачам развития Российской Федерации на период до 2024 года. Так, в Указе Президента «О нацио- 
нальных целях и стратегических задачах развития Российской Федерации на период до 2024 года» $[$ Указ ...] в числе целей «создание комфортных условий для проживания, а также условий и возможностей для самореализации и раскрытия таланта каждого человека», чему, несомненно, способствует активная общественная деятельность людей. Устанавливается, что при разработке национального проекта в сфере жилья и городской среды необходимо создать механизм прямого участия граждан в формировании комфортной городской среды, а также обеспечить к 2024 г. увеличение доли граждан, принимающих участие в решении вопросов развития городской среды, до 30 \%. Достижение целей, говорится в Указе, требует ускоренного внедрения цифровых технологий не только в экономике, но и в социальной сфере. Поэтому видится актуальной задача разработки концепции, выявления организационных, экономических инструментов и механизмов обеспечения эффективного общественного участия в формировании устойчивого города в рамках проекта «Умный город».

\section{Эволюция «умных» городов и их социально-общественного наполнения}

Из всех многочисленных определений понятия «умного» города нам ближе всего трактовка, сформулированная в 2013 г. Ренатой Паола Дамери (Университет Генуи), согласно которой «умный» город - это определенная географическая территория, в которой высокие технологии в таких областях, как информационно-коммуникационные технологии, логистика, производство электроэнергии и пр., соединены вместе для создания таких благ, как благополучие, вовлечение граждан в общественную жизнь и активное в ней участие, качество окружающей среды и умное развитие [Новиков, 2015].

В докладе Центра стратегических разработок «Северо-Запад» [Технологии ..., 2017] проведен анализ эволюции «умных» городов, выделены три условные фазы их становления, отражающие смену ключевых технологий и типов осуществляемых проектов.

К «умным» городам первой фазы развития концепции (Smart City 1.0) относят те, ко- торые возводились с нуля крупнейшими технологическими компаниями с целью апробирования разработанных решений. Согласно планам новый город полностью застраивался умными зданиями, прокладывались интеллектуальные энергетические и транспортные сети. Примеры Smart City 1.0: г. Сондго (Южная Корея), г. Масдар (ОАЭ), город-спутник Казани Иннополис (Россия). Попытки реализовать проекты создания «умного», а скорее «цифрового», города с нуля выявили следующие проблемы:

- ландшафт таких поселений «угнетающе стандартен», в них не формируется уникальная городская идентичность, а это чревато социальными проблемами;

- города обладают низкой адаптивностью (способность к восстановлению, адаптации к изменяющимся внешним и внутренним условиям считается необходимым свойством «умного» города наравне с устойчивостью);

- так как во все объекты города встроены технологические решения времен проектирования, то развитие технологий в современном темпе потребует через 10-15 лет полного переобустройства;

- элитарность - в силу того, что в подобных поселениях живут преимущественно обеспеченные люди, способные покупать набор дорогостоящих гаджетов, это может привести к сегрегации, высокому уровню преступности, росту социального напряжения.

Для городов второй фазы развития концепции (Smart City 2.0) большую роль приобретает комплексное стратегическое видение развития города. Для таких проектов требовалось тесное сотрудничество администрации города и крупной технологической компании. Ключевой тренд - внедрение комплексных цифровых систем управления городской инфраструктурой, позволяющих проводить мониторинг и диспетчеризацию критически важных объектов. В качестве критики таких проектов, отмечается в Докладе, говорят о низкой степени вовлечения граждан. Для перехода на новый уровень «умным» городам необходимо полноценное участие городских сообществ, неформальных групп работников, мелких частных предпринимателей и жителей пригородов. В качестве примеров городов уровня Smart City 2.0 можно назвать Барсе- 
лону (Испания), Рио-де-Жанейро (Бразилия), Пусан (Южная Корея), а также Санкт-Петербург (Россия).

Следующее поколение «умных» устойчивых городов обращается к задачам социального вовлечения, обеспечения равного доступа к технологиям, а также экономии бюджета и защиты окружающей природной среды. Горожане активно участвуют в проектах - делятся мнениями, используют и дополняют данные городских служб. Считается, например, что в городах будущего жители, отслеживая информацию или самостоятельно замерив качество воздуха на детских площадках или во всем районе, договариваются совместными усилиями со всеми заинтересованными сторонами о дополнительном озеленении и новых пешеходных зонах. То есть на третьей стадии «умный» город как сообщество граждан не только следует распоряжениям администрации, но и самостоятельно организует локальные проекты. В числе Smart City 3.0 называют, в первую очередь, Вену (Австрия), Сиэтл (США), Лондон (Великобритания). В некоторых публикациях к этой группе относят Москву (Россия), хотя это, скорее, из идеологических соображений.

В России применение концепции «умного» устойчивого города в практической плоскости происходит традиционным для нашей страны путем внедрения «сверху вниз».

Указом Президента РФ от 7 мая 2018 г. № 204 «О национальных целях и стратегических задачах развития РФ на период до 2024 года» было установлено девять национальных целей развития Российской Федерации, в том числе «обеспечение ускоренного внедрения цифровых технологий в экономике и социальной сфере».

Далее, Советом при Президенте РФ по стратегическому развитию и национальным проектам были одобрены двенадцать новых или скорректированных действующих национальных проектов, определенных вышеназванным Указом, в том числе новый национальный проект «Жилье и городская среда».

В состав каждого из национальных проектов включены федеральные проекты, на их основе разрабатываются ведомственные и планируется дальнейшая разработка региональных проектов. Так, 31 октября 2018 г. при- казом министра строительства и жилищнокоммунального хозяйства РФ во исполнение национального проекта «Жилье и городская среда» утвержден паспорт ведомственного проекта цифровизации городского хозяйства «Умный город». В паспорте указывается, что данный проект связан с действующими с 2017 г. Программой «Цифровая экономика» (ее проектом «Информационная инфраструктура») и Государственной программой РФ «Обеспечение доступным и комфортным жильем и коммунальными услугами граждан РФ».

Кроме того, сейчас вносятся коррективы в паспорт приоритетного проекта «Формирование комфортной городской среды» (действует с 2016 г. и теперь также является составной частью национального проекта «Жилье и городская среда»), учитывающие ряд мероприятий для «умных» городов, в том числе формирование муниципальных программ по благоустройству с учетом мнения граждан; территориального общественного самоуправления; реализацию механизма поддержки мероприятий по благоустройству, инициированных гражданами; финансового участия граждан и организаций в реализации указанных мероприятий; инструменты общественного контроля за реализацией мероприятий.

Проект Минстроя РФ «Умный город» рассчитан на шесть лет (с 1 декабря 2018 г. по 31 декабря 2024 г.) и становится объединяющим для проектов модернизации ЖКХ, формирования комфортной городской среды, повышения эффективности организации системы управления и планирования городскими ресурсами, создания инструментов вовлечения горожан в процессы управления городским хозяйством. Он базируется на пяти ключевых принципах: ориентация на человека, технологичность городской инфраструктуры, повышение качества управления городскими ресурсами, комфортная и безопасная среда, акцент на экономической эффективности.

\section{Феномен общественного участия как критерий «умных»
устойчивых городов}

В российской научной литературе термин «общественное участие» используется в по- 
давляющем числе случаев как родовое понятие, объединяющее различные виды - гражданское, собственно общественное и социальное участие. Распространенным является мнение, что участие - это инструментальная активность, посредством которой граждане пытаются влиять на правительство таким образом, чтобы оно предпринимало желаемые для них действия (см., например: [Гончаров и др., 1996, с. 146]). Подобные интерпретации участия встречаются в работах российских исследователей, посвященных изучению практики решения проблем в различных сферах образовании, градостроительстве, экологии, при этом взаимодействие с органами власти представляется одним из основных, а часто и единственным инструментом решения данных проблем [Скалабан, 2011, с. 134].

В методическом пособии «Общественное участие: теория и практика взаимодействия заинтересованных сторон в развитии местного сообщества», выпущенном КРОО ИнЭкА при финансовой поддержке Европейского союза и Всемирного фонда природы [Общественное участие ..., 2011], общественное участие рассматривается как «необходимое условие для улучшения проектов, обсуждения альтернатив, снижения социальных, экономических и экологических рисков при принятии управленческих решений», и даже используется термин «общественное участие в принятии решений» - процесс выявления и учета мнения заинтересованных сторон по обсуждаемому вопросу, обеспечивающий разработку и принятие эффективного управленческого решения.

В проекте Минстроя РФ «Умный город» дополнительным целевым показателем является доля жителей городов в возрасте старше 14 лет, имеющих возможность участвовать с использованием цифровых технологий в принятии решений по вопросам городского развития (через шесть лет таковых должно быть 60 \%). Существование этого показателя обусловлено наличием цели - создание механизма прямого участия граждан в формировании комфортной городской среды, увеличение доли граждан, принимающих участие в решении вопросов развития городской среды, до $30 \%$, поставленной в национальном проекте «Жилье и городская среда». При этом под гражданами, принимающими участие в решении вопросов развития городской среды, понимаются граждане Российской Федерации в возрасте с 14 лет, принявшие участие в мероприятиях, проводимых на территории муниципальных образований, в которых реализуются государственные (муниципальные) программы формирования современной городской среды. К числу основных мероприятий относятся: рейтинговое голосование, обсуждение конкретных проектов создания комфортной городской среды государственных (муниципальных) программ формирования современной городской среды, дизайн-проектов по конкретным территориям, использование цифровых технологий (мобильные приложения, онлайн порталы для голосования «Активный гражданин», «Добродел» и т. п.

Исследовав виды участия граждан в общественной жизни, характерные для нашей страны [Матова, 2018а], мы пришли к выводу, что в большинстве случаев речь идет о собственно общественном участии (то есть коллективной деятельности по достижению совместного социально значимого результата путем объединения индивидов в сообщества различной степени формализации, а также двунаправленном процессе взаимодействия между гражданами и органом власти, учреждением, ведомством), но с превалированием отношений и взаимодействий граждан и сообществ с местными органами власти, учреждениями и организациями в процессе формирования и реализации решений по вопросам местного самоуправления и городского хозяйства. В этом смысле указанное можно назвать гражданским участием («вертикальным участием», участием в партнерстве и управлении как форме коллективного управления), но без электоральной активности.

Несомненно, подобный вид общественного участия в «умном» устойчивом городе обеспечивает учет интересов всех слоев общества в процессе принятия управляющей системой решений путем обеспечения, в первую очередь посредством информационнокоммуникационных технологий, включенности граждан в обсуждение и разработку политических, социально-экономических, культурных программ и проектов, а также контроль над их исполнением). Общественное участие 
особенно важно при решении локальных проблем и конфликтов, к рассмотрению которых местные политики и чиновники часто подходят, не имея детальной информации об интересах всех участвующих сторон и не чувствуя конфликт «изнутри» (например: [Матова, 2018б]). Тем не менее роль общественного участия в «умном» устойчивом городе шире и не ограничивается лишь взаимодействием с властью, с управляющей системой территории. Так, в стандарте ISO 37101 «Устойчивое развитие административно-территориальных образований. Системы менеджмента качества. Общие принципы» [ГОСТ Р 565482015/ISO/DIS/37101] одна из шести задач устойчивого развития города формулируется как «социальная сплоченность», под которой понимаются справедливость, сокращение неравенства, толерантность, доступность. Совместное проживание, взаимозависимость и взаимопомощь подразумевают развитие коллективного и совместного образа жизни, который порождает взаимные экономические и социальные выгоды с точки зрения справедливости и социального лифта между поколениями и в пределах одного поколения.

\section{Проблемы применения различных форм общественного участия \\ в современных российских условиях}

Рассмотрим законодательно закрепленные формы участия населения в социальной жизни. В главе 5 Ф3-131 «Об общих принципах организации местного самоуправления в Российской Федерации» [Об общих принципах ... , 2003] устанавливаются 11 основных форм непосредственного осуществления населением местного самоуправления и участия населения в осуществлении местного самоуправления.

Результатом непосредственного осуществления местного самоуправления населением (пункты 1-4) является принятие властного решения по вопросам местного значения, так как эти решения являются обязательными. Однако эти механизмы партисипаторной демократии (за исключением выборов) используются на практике крайне редко, да и в муниципальных выборах принимает участие небольшое число жителей. Так, в единый день голосования 9 сентября 2018 г., когда прошли прямые выборы глав 22 регионов России, депутатов законодательных органов 16 субъектов Федерации и около 5 тысяч выборов в органы местного самоуправления, явка в среднем была $39 \%$, а учитывая, что «к президентским внимание всегда высокое, меньший интерес к парламентским и далее по нисходящей региональные и муниципальные избирательные кампании» [Зорина, 2018], то в выборах депутатов муниципальных органов самоуправления участвовал в среднем лишь каждый четвертый избиратель поселения. Следует отметить, что падение интереса к выборам и другим демократическим процедурам - это общемировой тренд. К примеру, на последних выборах мэра Лос-Анджелеса явка составила всего $20 \%$, а в Нью-Йорке 24 \% (2014 г.), тогда как в 1953 г. на выборы мэра Нью-Йорка пришло 93 \%.

Механизм участия населения в решении вопросов местного значения в формах, описанных в пунктах 5-11 Закона, предусматривает, что, помимо населения, в процедуре участвуют и другие субъекты - органы, должностные лица местного самоуправления. Задача применения форм этой группы ведет лишь к выявлению мнения жителей по конкретному вопросу, решать же этот вопрос будет так называемое «лицо, принимающее решение, субъект, наделенный полномочиями принимать решения и несущий ответственность за последствия принятого решения» [Общественное участие ..., 2011].

Распространенной формой участия населения в решении вопросов местного значения, носящей сегодня формально-институциональный характер, являются публичные слушания и общественные обсуждения. В силу того что Ф3-131 прямо обозначает ситуации, при которых публичные слушания или общественные обсуждения должны проводиться в обязательном порядке, эти формы общественного участия в значительной степени носят имитационный, или фиктивно-демонстративный, характер, когда самостоятельная активность жителей имитируется за счет нанятых и оплаченных «активистов», что еще больше снижает доверие населения к их результатам и сводит на нет желание участвовать в осуществлении местного самоуправления. Кроме того, потен- 
циал публичных слушаний и общественного обсуждения как форм участия населения в решении местных вопросов и общественного контроля деятельности исполнительной власти не может быть сегодня реализован в полной мере по причине отсутствия действенных механизмов учета общественного мнения и обратной связи.

Следует отметить, что, к сожалению, общественное участие в принятии решений, особенно в форме обращения граждан в органы местного самоуправления, часто носит характер так называемой иждивенческой активности, под которой исследователи условий повышения социальной активности граждан в решении местных проблем из Всероссийского совета местного самоуправления [Условия ...] понимают жалобы и прошения, направленные на то, чтобы другие акторы (власть, бизнес и т. п.) решили проблемы жителей, в том числе и те, за которые власть не отвечает. Соответственно, эффективность этой формы гражданского участия очень низка.

Среди форм участия населения в решении вопросов местного значения, предлагаемых законодателем, особый интерес представляет территориальное общественное самоуправление (ТОС), которое является самоорганизацией граждан, объединяющихся с целью самостоятельного и под свою ответственность осуществления собственных инициатив по вопросам местного значения. Оно предполагает высокую степень самоорганизации граждан, так как это не обязательная, а добровольная форма объединения людей по территориальному признаку, предполагающая возможность граждан самим определить сферу компетенции и проявить активность в ее реализации. Высказывается мнение, что на сегодняшний день ТОС являет собой ключевой механизм партнерского взаимодействия органов местной власти и местного сообщества [Безвиконная, 2017]. Анализ многочисленных исследований методологии и практики осуществления территориального общественного самоуправления в нашей стране позволил выявить две ключевые проблемы, препятствующие активному вовлечению россиян в деятельность ТОСов. Эти проблемы носят системный характер и являются препятствием появления, развития и эффектив- ного проявления всех форм общественного участия.

1. Дефицит доверия населения к институтам власти и убежденность в невозможности повлиять на их действия. Государственный патернализм в сочетании с порожденным им социальным инфантилизмом населения достались нашему обществу от советской политической и социальной системы взаимодействия и продолжают играть доминирующую роль в социальном поведении граждан [Аргунова, 2015]. Произошла трансформация декларируемой партисипаторной демократии в форму консультативной демократии: «...органы консультируются с гражданами не для того, чтобы при принятии публично-властных решений максимально учесть мнение населения, а для того, чтобы продемонстрировать наличие легитимации власти и показать широкую социальную базу этих актов» [Джагарян, 2017]. Низкий уровень доверия общественности к существующим формальным институтам общественного участия возникает вследствие неготовности органов государственной власти (в первую очередь из-за незнания соответствующих технологий) к переходу от «разговора с позиции силы» (в уведомительном порядке, в порядке информирования о выработанном решении и т. п.) к горизонтальной (коммуникационной, диалоговой) модели обсуждения, содержательному обоснованию и взаимодействию [Красникова и др., 2018].

2. Пассивность граждан в решении местных проблем. Причина ее, помимо основной неверия в возможность реально решать или влиять на решение вопросов жизнедеятельности локальной территории, кроется также в незнании, как правильно организовать совместную деятельность, недостаточной информированности о своих гражданских правах и формах их реализации, отсутствии свободного времени, низком уровне самосознания, «иждивенческих настроениях», низкой договороспоспособности россиян.

Кроме того, существует распространенная позиция, обосновывающая отказ заниматься вопросами благоустройства общественной жизни, помощи нуждающимся и прочими аспектами социального общежития - пришедшая с Запада «я за это плачу налоги». В то же время, к примеру, в Германии, где очень силь- 
но развито самоуправление, «общественная работа является почетной обязанностью гражданина, к которой еще не каждого подпускают» [Постовой, 1995].

Рассмотрим типы акторов, которым в наибольшей степени присущи разные роли и формы общественного участия. Е.В. Белокурова и Д.В. Воробьев в 2010 г. выделили три основных группы активных участников общественной жизни в нашей стране [Белокурова и др., 2010]:

1. Традиционные некоммерческие негосударственные организации, встроенные в реализацию социальной политики на локальном уровне, зачастую еще с советских времен: советы ветеранов, общества инвалидов, подростковые клубы и т. д.

2. Экспертные некоммерческие негосударственные организации, возникшие, как правило, в 1990-е гг., накопившие за это время богатый опыт экспертизы и обладающие высоким уровнем профессионализма. Чаще всего они официально зарегистрированы как юридические лица, включены во всероссийские и международные сети: правозащитные организации, такие как «Мемориал», «Солдатские матери», экологические центры и др.

3. Стихийные проблемно-ориентированные инициативы, возникающие как реакция на угрозы, значимые для населения территории в целом и/или для отдельных социальных групп. Как правило, это временные объединения граждан, которые используют в своей деятельности публичные мероприятия - «открытые, мирные, доступные каждому, проводимые в форме собрания, митинга, демонстрации, шествия или пикетирования либо в различных сочетаниях этих форм акции, осуществляемые по инициативе граждан...» [О собраниях ...], а также согласованный бойкот выборов улицей, микрорайоном, протестное голосование на выборах. Недостатками, снижающими эффективность протестной активности, является то, что альтернативные варианты действий и решений не рассматриваются, а также неформальный, добровольный характер деятельности, неустойчивый, временный, зачастую случайный характер контактов между ключевыми действующими лицами, рассогласованность интересов участников.
Сегодня необходимо отметить тенденцию качественного изменения гражданской культуры российского общества - становление и активное развитие неформальных сообществ людей, объединенных общими ценностями и интересами (а не проблемами) для достижения совместного социально значимого результата. Под сообществом в социальном контексте мы понимаем группу людей, активно и регулярно общающихся между собой и объединенных, как правило, географически по одному или нескольким из следующих признаков:

- общие цели, интересы, потребности;

- общие ресурсы или активы, к которым члены сообщества имеют доступ;

- общие социальные нормы, культура, контекст и язык общения, в который погружены члены сообщества.

\section{Условия повышения эффективности общественного участия \\ в формировании устойчивого города}

На основании анализа проблем и препятствий, снижающих как активность общественного участия, так и его эффективность в обеспечении устойчивого развития поселения, были определены условия, позволяющие использовать потенциал различных форм общественного участия.

1. Осознанный переход от централизованной структуры организации сообществ (институциональных, формальных и неформальных) и формы взаимодействия между ними к децентрализованной. Децентрализованная структура может быть организована по принципу «Р2P» (peer to peer) - равноправных узлов, когда каждый может связываться с каждым, или на основе механизмов, заложенных в холакратии - социальной технологии управления, в которой полномочия и ответственность за принятие решений распределяются по всей системе самоорганизующихся единиц (в контексте исследования людей или сообществ) [Робертсон, 2015], или с использованием таких инструментов, как «открытый оргкомитет» (выбор участниками функциональных ролей происходит в каждом проекте или событии в соответствии с имеющимися компетенциями, ресурсами и 
целями; открытость и последовательность информации о процессах, позволяющие включиться любому заинтересованному лицу на любом этапе реализации проекта) и «лидерство по запросу», или применяя методологии формирования и деятельности самоорганизующейся и самоуправляемой команды Scrum (Скрам), Аджайл (Agile) и т. п. Применение такого подхода повышает устойчивость сообщества, обеспечивает предсказуемость и стабильность действий, уменьшает зависимость его существования и направления развития от одной или нескольких личностей (традиционного лидера).

2. Применение современных организационных, а также экономических инструментов и механизмов, обеспечивающих эффективную деятельность сообществ (от институциональных до неформальных), возможно при условии наличия у участников общественной (гражданской, социальной) жизни высокой культуры взаимодействия и коммуникации, новых компетенций и соответствующих знаний. Следовательно, ключевую роль играет обучение, передача технологий, распространение знаний и лучших практик их применения, причем не только среди жителей и активистов, но и среди чиновников и других лиц, принимающих решение с участием общественности. Сегодня подобную образовательную функцию выполняют, например, некоммерческое образовательное учреждение Институт медиа, архитектуры и дизайна «Стрелка», сеть городских сообществ «Центр прикладной урбанистики». Представляется, что задачу обучения, консультирования и распространения знаний, навыков, опыта в организации взаимодействия, построении диалога, нахождении консенсуса, формировании эффективных решений должны взять на себя и муниципальные органы власти, формируя тем самым общественномуниципальное партнерство.

3. Использование цифровых технологий для повышения эффективности общественного участия в рамках проекта «Умный город». Основываясь на анализе целей, форм и видов общественного участия, сформулируем ключевые задачи, которые должны решаться в устойчивом поселении на основании специальных регламентированных процедур и с исполь- зованием цифровых информационно-коммуникационных технологий «умного» города.

Во-первых, задача организации эффективного общественного участия в принятии решения по вопросам местного самоуправления должна быть решена на базе пятиступенчатой процедуры учета мнения заинтересованных сторон [Общественное участие ..., 2011]:

1. Информирование горожан о происходящих процессах, событиях, явлениях во всех сферах городской жизни (социальной, экологической, экономической) по актуальным для горожан направлениям на различных информационных и коммуникационных площадках. Важным аспектом является обеспечение в рамках «умного» города интерактивности этого процесса, а именно участия граждан в формировании информационной базы путем предоставления им прав и технической возможности вносить имеющиеся данные о происходящих в городе процессах, событиях, явлениях, что позволит выявить проблемы, конфликты интересов на ранней стадии появления до того, как они найдут свое отражение в официальных данных.

2. Выявление мнений горожан - выполнение требование п. 4.4 «Понимание потребностей и ожиданий заинтересованных сторон» стандарта ISO 37101. Здесь необходимо использовать наработанный опыт создания специальных сайтов для обсуждения проектов стратегических документов регионального уровня в России, как положительные его стороны, так и выявленные недостатки и проблемы [Красникова и др., 2018].

3. Обсуждение проектов и вариантов решения на принципах открытости, прозрачности, пользовательской доступности и удобства. Создается площадка для конструктивного диалога между лицом, принимающим решение, и представителями заинтересованных сторон.

4. Принятие решений - действующие муниципальные правовые акты, регламентирующие процедуру участия жителей в формировании решений и, соответственно, обеспечивающие их технические, технологические и информационно-коммуникационные инструменты, должны гарантировать, что итоговое решение будет принято с учетом мнения на- 
селения. Это повысит доверие общественности к существующим институтам общественного участия, обеспечит активность обсуждения, что является необходимым условием выработки эффективного управленческого решения.

5. Обратная связь - после принятия итогового решения необходимо проинформировать заинтересованные стороны о том, какое решение было принято, какие мнения были учтены и каким образом, какие мнения не были учтены и почему. Отчеты о причинах, по которым мнения не были учтены, являются, в том числе, обучающим инструментом, способствующим тому, что в последующем заинтересованные стороны будут высказывать более обоснованные и компетентные мнения. Это очень важный этап, который обычно недооценивают в российской практике.

Во-вторых, задача формирования условий для самоорганизации горожан как основы построения гражданского общества может решаться в рамках проекта «умный» город по следующим направлениям:

- предоставление жителям инструментов (координационных платформ), позволяющих организовать и в необходимой степени формализовать сообщества в цифровом пространстве, а также обеспечить эффективные формы и способы коммуникации граждан и сообществ;

- обеспечить (технологически, процессуально и технически) прозрачные и симметричные коммуникацию и взаимодействие между горожанами, сообществами (как схожими, так и различающимися своими целями) и органами местного самоуправления, государственной власти, организациями и учреждениями различных ведомств - для перехода к партнерской коммуникации с местными сообществами: интерактивного координирования целей, задач, решений, деятельности, выявления и оперативного решения возникающих конфликтов интересов.

\section{Выводы}

Перспектива активизации и повышения эффективности использования всех форм непосредственного осуществления населением местного самоуправления и участия населения в решении локальных задач, а также ее перевод в конструктивную плоскость лежит, на наш взгляд, в усилении процессов самоорганизации жителей, создании условий и предпосылок для возникновения неформальных систем и сетей как основы устойчивой социальной системы города. В процедуре обеспечения общественного участия в принятии решений наличие сформировавшихся сообществ позволяет лицу, принимающему решение, работать уже не с мнениями отдельных людей, а с сообществами, внутри которых выдвигаемые идеи и мнения прошли активное обсуждение. Очень важно на этом этапе создать культуру и навыки конструктивной активности - инициативы жителей в виде попытки выработки консенсуса и корректировки действий участников ситуации для создания более благоприятных условий жизнедеятельности на территории, партнерское взаимодействие всех заинтересованных сторон.

\section{СПИСОК ЛИТЕРАТУРЫ}

Аргунова, Л. Г. Территориальное общественное самоуправление как институт гражданского общества / Л. Г. Аргунова // Материалы Афанасьевских чтений. - 2015. - № 13. C. $179-182$.

Безвиконная, Е. В. Муниципальная власть как актор социально-политического взаимодействия с территориальным общественным самоуправлением (на материалах практик городских округов) / Е. В. Безвиконная // Вестник Омского университета. Серия: Исторические науки. - 2017. - № 3 (15). - С. 435-444.

Белокурова, Е. В. Общественное участие на локальном уровне в современной России / Е. В. Белокурова, Д. В. Воробьев // Неприкосновенный запас. Дебаты о политике и культуре. 2010. - № 2. - 30 мая. - Электрон. текстовые дан. - Режим доступа: http://www.intelros.ru/ readroom/nz/nz_70/6494-obshhestvennoeuchastie-na-lokalnom-urovne-v-sovremennojrossii.html (дата обращения: 23.01.2019). - Загл. с экрана.

Гончаров, Д. В. Введение в политическую науку / Д. В. Гончаров, И. Б. Гоптарева. - М. : Юрист, 1996. $-232 \mathrm{c}$.

ГОСТ Р 56548-2015/ISO/DIS/37101. Устойчивое развитие административно-территориальных образований. Системы менеджмента каче- 
ства. Общие принципы и требования. - Электрон. текстовые дан. - Режим доступа: http:// docs.cntd.ru/document/1200124250 (дата обращения: 28.01.2019). - Загл. с экрана.

Джагарян, А. В. Общественный элемент муниципального представительства и его влияние на сбалансированность частных и публичных интересов / А. В. Джагарян // Юридический вестник ДГУ. - 2017. - Т. 21, № 1. - С. 36-43.

Зорина, А. Политологи оценили явку на выборах в Единый день голосования городов / А. Зорина // Портал Политэксперт. 09.09.2018. Электрон. текстовые дан. - Режим доступа: https://politexpert.net/119928-politologiocenili-yavku-na-vyborakh-v-edinyi-dengolosovaniya (дата обращения: 26.01.2019). Загл. с экрана.

Красникова, Т. С. Проблемы вовлечения общественности в процесс стратегического планирования в России: явлются ли цифровые технологии выходом? / Т. С. Красникова, В. Г. Марача // Региональная экономика. Юг России. 2018. - № 1 (19). - C. 101-109. - DOI: https:// doi.org/10.15688/re.volsu.2018.1.9.

Матова, Н. И. Феномен общественного участия как критерий «умных» устойчивых городов / Н. И. Матова // Социальные, экономические, технологические и экологические аспекты устойчивого развития регионов России : сб. науч. ст. Всерос. науч. конф. - Сочи : ИП Кривлякин С.П., Тип. «Оптима», 2018а. С. 254-261.

Матова, Н. И. Формы общественного участия в формировании ООПТ местного значения как элемента «зеленой» инфраструктуры устойчивого города / Н. И. Матова // Устойчивое развитие особо охраняемых природных территорий. Т. 5 : сб. ст. V Всерос. науч.-практ. конф. - Сочи : ГКУ КК «Природный орнитологический парк в Имеретинской низменности», Донской издательский центр, 2018б. С. 204-210.

Новиков, И. В. Роль МСЭ в стандартизации умных устойчивых городов / И. В. Новиков // Вестник Московского университета им. С.Ю. Витте. Серия 1, Экономика и управление. - 2015. № 3 (18). - С. 74-79.

О собраниях, митингах, демонстрациях, шествиях и пикетированиях : федер. закон от 19.06.2004 № 54-Ф3. - Электрон. текстовые дан. - Режим доступа: http:/www.consultant.ru/document/ cons_doc_LAW_48103/ (дата обращения: 21.01.2019). - Загл. с экрана.

Об общих принципах организации местного самоуправления в Российской Федерации : федер. закон от 06.10.2003 № 131-Ф3. - Электрон. текстовые дан. - Режим доступа: http://www.consultant.ru/ document/cons_doc_LAW_44571 (дата обращения: 23.01.2019). - Загл. с экрана.

Общественное участие: теория и практика взаимодействия заинтересованных сторон в развитии местного сообщества / авт.-сост.: Е. В. Перфильева [и др.]. - Петропавловск-Камчатский, 2011. $-46 \mathrm{c}$.

Постовой, Н. В. Местное самоуправление: история, теория, практика / Н. В. Постовой. - М. : Рекламно-издательский центр «Федоров», 1995. -189 с

Приоритетный проект «Формирование комфортной городской среды» : Презентация, 2018. - Электрон. текстовые дан. - Режим доступа: http:// www.minstroyrf.ru/upload/iblock/64a/ prezentatsiya-prioritetnogo-proektaformirovanie-komfortnoy-gorodskoy-sredyminstroya-rossii.pdf (дата обращения: 05.02.2019). - Загл. с экрана.

Робертсон, Б. Холакратия. Революционный подход в менеджменте / Б. Робертсон. - М. : Эксмо, 2015. - $250 \mathrm{c}$.

Скалабан, И. А. Социальное, общественное и гражданское участие: к проблеме осмысления понятий / И. А. Скалабан // Вестник Томского государственного университета. Серия «Философия. Социология. Политология». 2011. - № 1 (13). - С. 130-139.

Технологии для умных городов : Доклад// Центр стратегических разработок «Северо-Запад». - СПб., 2017. - 107 с. - Электрон. текстовые дан. - Режим доступа: http://csr-nw.ru/files/publications/ doklad_tehnologii_dlya_umnyh_gorodov.pdf (дата обращения: 07.02.2019). - Загл. с экрана.

Указ «О национальных целях и стратегических задачах развития Российской Федерации на период до 2024 года». - Электрон. текстовые дан. - Режим доступа: http://www.kremlin.ru/ events/president/news/57425 (дата обращения: 21.01.2019). - Загл. с экрана.

Условия повышения социальной активности граждан в решении местных проблем : Аналитический отчет Всероссийского Совета местного самоуправления. - Электрон. текстовые дан. - Режим доступа: http://www.vsmsinfo.ru/ proekty-i-programmy/interesnye-proekty/2722 (дата обращения: 12.12.2018). - Загл. с экрана.

Mapping Smart Cities in the EU // European Parliament. 2014. - Electronic text data. - Mode of access: http://www.europarl.europa.eu/ RegData/etudes/etudes/join/2014/507480/ IPOL-ITRE_ET(2014)507480_EN.pdf(date of access: 21.12 .2018$)$. - Title from screen. 


\section{REFERENCES}

Argunova L.G. Territorial'noe obshhestvennoe samoupravlenie kak institut grazhdanskogo obshhestva [Local public self-government as institute of civil society]. Materialy Afanas'evskikh chtenij [Materials of Afanasyevsky readings], 2015, no. 13 , pp. 179-182.

Bezvikonnaya E.V. Municipal'naya vlast' kak aktor social'no-politicheskogo vzaimodejstviya s territorial'nym obshhestvennym samoupravleniem (na materialakh praktik gorodskikh okrugov) [Municipal authority as an actor of sociopolitical interaction with territorial public self-government (based on the practices of urban districts)]. Vestnik Omskogo universiteta. Series "Historical sciences”, 2017, no. 3 (15),pp. 435-444.

Belokurova E.V., Vorob'ev D.V. Obshhestvennoe uchastie na lokal'nom urovne v sovremennoj Rossii [Public participation at the local level in modern Russia]. Neprikosnovennyj zapas. Debaty o politike i kul 'ture [Emergency ration. Politics and Culture Debate], 2010, no. 2. URL: http://www.intelropp.ru/readroom/nz/nz_70/ 6494-obshhestvennoe-uchastie-na-lokalnomurovne-v-sovremennoj-rossii.html (accessed 23 January 2019)

Goncharov D.V., Goptareva I.B. Vvedenie v politicheskuyu nauku [Introduction to Political Science]. Moscow, Yurist, 1996, 232 p.

GOST R 56548-2015/ISO/DIS/37101. Ustojchivoe razvitie administrativno-territorial'nyh obrazovanij. Sistemy menedzhmenta kachestva. Obshhie principy [Sustainable development and resilience of communities. Management systems. General principles and requirements: GOST R 56548-2015/ISO/DIS/ 37101]. URL: http://docpp.cntd.ru/document/ 1200124250 (accessed 28 January 2019).

Dzhagaryan A.V. Obshhestvennyj e'lement municipal'nogo predstavitel'stva i ego vliyanie na sbalansirovannost' chastnyx i publichnykh interesov [The public element of the municipal representation and its impact on the balance of private and public interests]. Yuridicheskij vestnik $D G U, 2017$, vol. 21, no. 1, pp. 36-43.

Zorina A. Politologi ocenili yavku na vyborax v Edinyj den' golosovaniya gorodov [Political analysts rated the turnout in the elections on a Single day of voting cities]. Portal Polite'kspert [Political expert portal]. URL: https:// politexpert.net/119928-politologi-ocenili-yavkuna-vyborakh-v-edinyi-den-golosovaniya (accessed 26 January 2019).

Krasnikova T.S., Maracha V.G. Problemy vovlecheniya obshhestvennosti v process strategicheskogo planirovaniya v Rossii: yavlyutsya li cifrovye texnologii vyxodom? [Problems of public involvement in the strategic planning process in Russia: is digital technology a way out?]. Regional'naya e'konomika. Yug Rossii, 2018, no. 1 (19), pp. 101-109. DOI: https://doi.org/ 10.15688/re.volsu.2018.1.9.

Matova N.I. Fenomen obshhestvennogo uchastiya kak kriterij «umnykh» ustojchivykh gorodov [The phenomenon of public participation as a criterion for smart sustainable cities]. Social 'nye, e'konomicheskie, tekhnologicheskie $i$ e'kologicheskie aspekty ustojchivogo razvitiya regionov Rossii: sb. nauch. st. Vseross. nauch. konf [Social, economic, technological and environmental aspects of sustainable development of Russian regions: Proc. Russian Scientific Conf.]. Sochi, 2018a, pp. 254-261.

Matova N.I. Formy obshhestvennogo uchastiya v formirovanii OOPT mestnogo znacheniya kak e'lementa «zelenoj» infrastruktury ustojchivogo goroda [Forms of public participation in the formation of local protected areas as an element of the green infrastructure of a sustainable city]. Ustojchivoe razvitie osobo okhranyaemykh prirodnyhk territorij: sb. st. VVseross. nauch.prakt. konf. [Sustainable development of specially protected natural areas: Proc. $5^{\text {th }}$ Russian Scientific Conf.]. Sochi, 2018b, vol. 5, pp. 204-210.

Novikov I.V. Rol MSE v standartizatsii umnykh ustoychivykh gorodov [Role of the International Telecommunication Union in Standardisation of Smart Sustainable Cities]. Vestnik Moskovskogo universiteta im. S.Yu. Vitte. Seriya 1: Ekonomika i upravlenie [Moscow Witte University Bulletin. Series 1: Economics and Management], 2016, no. 3 (18), pp. 74-79.

O sobraniyakh, mitingakh, demonstraciyakh, shestviyakh i piketirovaniyakh: feder. zakon ot 19.06.2004 N 54-FZ [On meetings, rallies, demonstrations, processions and picketing: federal law]. URL: http://www.consultant.ru/ document/cons_doc_LAW_48103/ (accessed 21 January 2019).

Ob obshhikh principakh organizacii mestnogo samoupravleniya $v$ Rossijskoj Federacii: feder. zakon ot 06.10.2003 N 131-FZ [On the general principles of the organization of local self-government in the Russian Federation: federal law]. URL: http://www.consultant.ru/ document/cons_doc_LAW_44571 (accessed 23 January 2019).

Obshhestvennoe uchastie: teoriya i praktika vzaimodejstviya zainteresovannyx storon v razvitii mestnogo soobshhestva [Public Participation: 
Н.И. Матова. Проблемы и условия эффективного общественного участия в формировании «умного» города

Theory and Practice of Stakeholder Interaction in the Development of the Local Community]. Petropavlovsk-Kamchatskij, 2011.46p.

Postovoj N.V. Mestnoe samoupravlenie: istoriya, teoriya, praktika [Local Self-Government: History, Theory, Practice]. Moscow, Adv.-ed. center Fedorov, $1995.189 \mathrm{p}$.

Prioritetnyj proekt «Formirovanie komfortnoj gorodskoj sredy»: Prezentaciya [Priority project "Formation of a comfortable urban environment": Presentation], 2018. URL: http://www.minstroyrf.ru/ upload/iblock/64a/prezentatsiya-prioritetnogoproekta-formirovanie-komfortnoy-gorodskoysredy-minstroya-rossii.pdf (accessed 05 February 2019).

Robertson, B. Holakratiya. Revolyucionnyj podxod $v$ menedzhmente [Holacratia. A revolutionary approach to management]. Moscow, Eksmo Publ., 2015. 250 p.

Skalaban I.A. Social'noe, obshhestvennoe i grazhdanskoe uchastie: k probleme osmysleniya ponyatij [Social, public and civic participation: to the problem of understanding the concepts] Vestnik Tomskogo gosudarstvennogo universiteta [Bulletin of Tomsk State University]. Vol. Philosophy Series. Sociology. Political Science, 2011, no. 1 (13), pp. 130-139.
Tekhnologii dlya umnykh gorodov. Doklad [Technologies for smart cities. Report]. URL: http://csr-nw.ru/files/publications/ doklad_tehnologii_dlya_umnyh_gorodov.pdf (accessed 07 February 2019).

Ukaz «O nacional'nykh celyakh $i$ strategicheskikh zadachakh razvitiya Rossijskoj Federacii na period do 2024 goda» [On the national goals and strategic objectives of the development of the Russian Federation for the period up to 2024: Decree]. URL: http://www.kremlin.ru/ events/president/news/57425 (accessed 21 January 2019).

Usloviya povysheniya social'noj aktivnosti grazhdan $v$ reshenii mestnyx problem: Analiticheskij otchet Vserossijskogo Soveta mestnogo samoupravleniya [Conditions for increasing the social activity of citizens in solving local problems: Analytical report of the Russian Council of Local Self-Government]. URL: http:// www.vsmsinfo.ru/proekty-i-programmy/ interesnye-proekty/2722 (accessed 12.12.2018).

Mapping Smart Cities in the EU// European Parliament, 2014. URL: http://www.europarl.europa.eu/ RegData/etudes/etudes/join/2014/507480/IPOLITRE_ET(2014)507480_EN.pdf (accessed 21 December 2018).

\section{Information about the Author}

Natal'ya I. Matova, Candidate of Sciences (Economics), Senior Researcher, Laboratory of Environmental Economics and Ecology, Branch of the Institute of Natural and Technical Systems, Kurortnyy Prosp.,99/18, 354024 Sochi, Russian Federation, 1elj06@yandex.ru, https://orcid.org/0000-0001-6084-6233

\section{Информация об авторе}

Наталья Ивановна Матова, кандидат экономических наук, старший научный сотрудник лаборатории экономики природопользования и экологии, Институт природно-технических систем (Филиал), Курортный просп., 99/18, 354024 г. Сочи, Российская Федерация, lelj06@yandex.ru, https://orcid.org/0000-0001-6084-6233 